DOI https://doi.org/10.32837/app.v0i67.1149

УДК 342

\author{
М. М. Богаченко \\ orcid.org/0000-0003-1913-6349
}

аспірант кафедри парламентаризму та політичного менеджменту

Національної академї̈ державного управління при Президентові України

\title{
СУЧАСНІ НАУКОВІ КОНЦЕПЦІЇ ПОЛІТИЧНОГО МЕНЕДЖМЕНТУ
}

Пандемія коронавірусу та спроби її подолання в Україні чітко виявили як відсутність ефективного управління ресурсами нашої країни, так і брак тривалого стратегування. Саме ці обставини актуалізують необхідність розгляду наукових концепцій дослідження проблематики політичного менеджменту як галузі політичної науки, що охоплює принципи, форми, методи, прийоми і засоби управління матеріальними і людськими ресурсами заради досягнення мети політичного розвитку.

Потрібно відзначити, що поняття «політичний менеджмент» $є$ похідним від уявлень про «класичний менеджмент», яке було сформовано у працях Ф. Тейлора, А. Файоля, Г. Емерсона, Л. Урвіка, Е. Мейо, П. Дракера, Г. Саймона, А. Етционі, Л. Берталанфі (Щербак, 2015, с. 19-20). Цей напрям засновувався на напрацюваннях так званого «індустріального менеджменту», змістом якого була організація фабричної праці на основі самостійної відповідальності персоналу з метою отримання якомога більшої віддачі від праці робітників. Основними постулатами цієї (історично першої) форми менеджменту є машинна праця і розподіл та економіка спеціалізації. Індустріальний менеджмент досліджували такі теоретики, як Ч. Беббідж, Е. Юр, Г. Таун, Г. Меткалф та Х. Мюнстенберг (Шульга, 2013).

Вже наприкінці XIX ст. виникло уявлення про «науковий менеджмент», яскравими представниками якого були Ф. Тейлор, подружжя Гілбертів, А. Файоль, А. Стоун. Згодом менеджмент було збагачено працями, що розкривали вплив «людських відносин» на індустріальну ефективність (активно розвивали М. Фолет, Е. Мейо та інші). 3 часом до концепщій менеджменту було додано: 1) «теорію мотивації» А. Маслоу (Maslow, 1954); 2) «мотиваційно-гігієнічну теорію» Ф. Херцберга (Herzberg, 1959); 3) концепцію «теорія Х» та «теорія Ү» Д. Макгрегоpa (Carson, 2018); 4) здобутки «японської моделі» менеджменту (Майструк, 2007).

У сучасній західній науці появу такого відгалуження, як «політичний менеджмент», пов' язують зі спробами адаптувати праці М. Вебера, А. Гідденса, Р. Дарендорфа, П. Блінда, Б. Ньюмана та інших до основних постулатів «класичного менеджменту» у контексті пошуку способів ефективного управління демократичним суспільством (Blind, 2007; Newman, 2010). Так, американський політолог Г. Вільсон зазначає, що політичний менеджмент є спробою поєднати представницькі та демократичні процеси з ефективним управлінням в інтересах суспільства (Wilson, 1985).

У цьому контексті показовою є думка Дж. Шелдрейка, що менеджмент початку XXI ст. має зважати на таке: людина - це найбільша цінність для самої себе, захист їі інтересів - головна функція держави, а бізнес повинен піклуватися про благополуччя особи, причому не лише матеріальне, а й духовне; діяльність господарських організацій здійснюється в інтересах людей, при цьому на сучасному рівні техніки та технології - часто в інтересах не групи, нації чи народу, а окремої особистості; досягнення цілей організації здійснюється через людей, від їхнього ставлення до того, що вони роблять, безпосередньо залежить результат (цитата за Шульгою, 2013).

Щодо пострадянського наукового середовища, то вказана проблематика не тільки знайшла своє відображення у численних дослідженнях (наприклад, В.М. Бебика, В. Бойка, М.Ф. Головатого, В.О. Корнієнка, Ю.І. Палехи, Л.В. Полякова, Г.Г. Почепцова, В.М. Приймака, Г.В. Пушкарьової, Ф.І. Хміля, Г.В. Щокіна), а й відрізняється розмаїттям понятійних визначень політичного менеджменту.

На нашу думку, у межах вітчизняної науки можна виокремити два магістральні підходи. Так, до першого можна віднести «широке трактування» політичного менеджменту, яке за- 
сновується на визнанні необхідності розглядати політичний процес як площу зіткнень різноманітних інтересів, що вбирають у себе різноспрямовані впливи, ініціатори та суб'єкти яких переслідують загальні чи специфічні цілі (наприклад, Нежданов, 2008; Шульга, 2013).

У цих межах показовим є зведення політичного менеджменту до мистецтва управління державою, що являє собою сукупність державних (політичних) ідей, спрямовану на вироблення ефективних управлінських механізмів, цілеспрямовану діяльність, пов'язану з формуванням життєво важливих відносин між державами, народами, націями, класами, різними соціальними групами суспільства (Бебик, 2011, с. 5).

Так, В.О. Корнієнко, один із авторів «Прикладної політології» (Горбатенко, 2008), наголошує на тому, що «політичний менеджмент є одночасно як наукою, так і мистецтвом управління» (Горбатенко, 2008, с. 95), це система управління політичними процесами (Горбатенко, 2008, с. 96]. I далі дає таке тлумачення політичного менеджменту: «Політичний менеджмент особливий вид управління в політиці, наука і мистецтво аналізу тенденцій політичного розвитку, передбачення його наслідків, вироблення рекомендацій для політичного керівництва, забезпечення їх реалізації в політичній практиці (Горбатенко, 2008, с. 96).

На думку М.Й. Беззуб'яка, розгляд політичної дійсності у межах політичного менеджменту означає, що у полі наукового аналізу опиняється: 1) покроковий шлях прийняття політичного рішення; 2) аналіз конкретної ситуації, що потребує прийняття рішення; 3) розроблення рішення (проекту, програми); 4) затвердження результату розроблення і прийняття його до виконання; 5) здійснення ухваленого рішення; 6) вивчення реальних наслідків здійснення рішення і можливості підсилення його позитивних наслідків (Беззуб'як, 2012, с. 582).

До другого підходу можна віднести «вузьке розуміння» політичного менеджменту як різновиду практичної політології, з акцентуванням на психологічних засадах, структурних компонентах, організаційній культурі, засадах виборчих компаній, технологіях впливу на прийняття управлінських рішень. (Перевозник, 2012, с. 97). Наприклад, показовим є зведення політичного менеджменту до виборчої кампанії, діяльності правлячої (або урядової) команди й окремої політичної кампанії з рекламування певних цінностей, доктрин, програм тощо. У цьому контексті можна говорити про такі основні види політичного менеджменту.

1. Іміджмейкинг: створення образу, іміджу державного, політичного діяча, привабливого для широких мас.

2. Корпоративний політичний іміджмейкинг: формування в масовій свідомості впізнаваного позитивного образу державної установи, політичної організації, партії.

3. Електоральні технології як системна організація передвиборної кампанії.

4. Політичний брендинг (бренд - торгова марка): внесення в масову свідомість впізнаваних символів, значень, образів, здатних відповідно до цілей суб'єкта політико-технологічного управління об'єднувати людей або, навпаки, роз'єднувати їх на групи, що змагаються.

5. Технології політичних союзів як діяльність, орієнтована на залучення у вирішення поставлених завдань своїх політичних союзників і опонентів.

6. Технології регулювання і вирішення політичних конфліктів, що передбачають пошук шляхів і засобів зниження політичного протистояння і політичної напруженості в суспільстві.

7. Технології лобізму, що є діяльністю, спрямованою на завдавання впливу на державних посадовців, що ухвалюють управлінські рішення (Пахомов, 2011).

На нашу думку, можна погодитися із твердженням Л. Перевозник, що політичний менеджмент займає особливе місце між прикладною та теоретичною галузями політичної науки, оскільки саме «зростаючий політичний попит на політичні послуги може задовольнити своєю пропозицією політичний менеджмент» (Перевозник, 2012, с. 97).

Відзначимо, що більшість вітчизняних дослідників виокремлюють види політичного менеджменту залежно від основних сфер людської діяльності, таких як соціально-політичний менеджмент та адміністративно-державне управління. Популярним є виокремлення таких форм самого політичного менеджменту, як: державний, державно-адміністративний, урядовий і технологічний, де процес управління розглядають на різних рівнях управлінської ієрарxiї: загальнодержавному, регіональному, місцевому, галузевому тощо. 
У цьому сенсі виправданим є звернення до зауваження В.М. Бебика, що подібні визначення політичного менеджменту відрізняються певною спрощеністю, оскільки ці підходи відображають практичний аспект політики, а саме безперервний розгляд, ухвалення, а головне практичне втілення політичних рішень, настанов тощо (Бебик, 2011, с. 5).

На нашу думку, відсутність загальновизнаного значення терміна «політичний менеджмент» пов' язана з необгрунтованим змішуванням дескриптивного і конструктивного методів формування поняття, що відображають різні аспекти понятійного наповнення.

Так, О. Морозова стверджує: «політичний менеджмент або політичне управління постають перед нами як важливий інституціональний механізм трансляції політичних традицій, накопичення і реалізації реального політичного досвіду, розвитку політичних інновацій у межах реалізації політичних інтересів різних соціальних інститутів, груп і окремих індивідів» (Зиновьев, 2009). Це судження, з одного боку, розкриває співвідношення між двома об'єктами політичним менеджментом і політичним управлінням, що характеризує його як дескриптивне. 3 іншого боку, воно описує властивості самого об'єкта - політичного менеджменту, що $є$ ознакою конструктивного підходу.

Проте конструктивне визначення терміна передбачає безпосередній опис об'єкта як явища, саме з'ясування об'єктивної форми його існування та структури. У таких межах визначають політичний менеджмент українські політологи М. Шульга і О. Зубчик. На їхню думку, політичний менеджмент - це система управління політичними процесами, основою якої $є$ аналіз тенденцій політичного розвитку з метою передбачення його наслідків та вироблення рекомендацій для політичного керівництва і забезпечення їх реалізації в політичній практиці (Шульга, 2013).

Усе вищевказане дає змогу констатувати, що визначення політичного менеджменту у межах вітчизняної політичної науки охоплює діяльність політиків, державних органів, структур, пов' язане з управлінням державою, досягненням у ньому певних повноважень, владних функцій, впливом на формування цілей його розвитку та їх досягнення. Як головна функція політичного менеджменту розглядається забезпечення інтегральної цілісності, єдності, безпеки і добробуту своїх громадян і країни загалом за рахунок вмілого керівництва та ефективного управління. Іноді під терміном «політичний менеджмент» розуміється і система поглядів, яка визначає основні напрями політичної діяльності, тому участь у владних структурах і здійснення впливу на владні функції - головний зміст політичного менеджменту як головної функціональної технології XXI ст.

Як можна побачити, існують істотні розбіжності у трактуванні поняття «політичний менеджмент» у межах зарубіжної та вітчизняної політичної науки. Ці розбіжності пов'язані 3 тим, що для зарубіжної політичної науки притаманним є розмежування між політичним менеджментом та політичним маркетингом як практичною діяльністю політичних суб'єктів (партій, блоків тощо) з упровадження в суспільну свідомість певних соціально-політичних, ідеологічних цінностей, ідей, програм розвитку окремої території чи держави загалом, на відміну від вітчизняної науки, де досить часто ці поняття розглядають як синоніми. Наприклад, Ф.М. Рудич висловлює думку, що «політичний менеджмент» - це наука й мистецтво аналізу тенденцій політичного розвитку, передбачення його наслідків, вироблення рекомендацій для політичного керівництва та забезпечення реалізації цих рекомендацій у політичній практиці. Зрештою, політичний менеджмент - це система управління політичною сферою суспільства на засадах використання форм, методів і технологій політичного маркетингу і правового менеджменту» (Рудич, 2004, с. 180-181).

B.М. Бебик визначає політичний менеджмент як, по-перше, систему управління політичною сферою суспільства на основі використання форм, методів і технологій правового менеджменту та політичного маркетингу, що передбачає безпосередній розгляд, ухвалення та втілення в життя політичних рішень. (Бебик, 2009, с. 426). По-друге, політичний менеджмент $\epsilon$ функцією спеціалізованої групи людей (політичної, правлячої еліти), яка домагається необхідної поведінки людей - членів суспільства - за допомогою правових норм, умовлянь і маніпулювання. 
Все вищенаведене засвідчує необхідність подальшого висвітлення проблеми наукових концепцій політичного менеджменту, оскільки: 1) значення цієї сфери діяльності постійно зростає; 2) вибір трактування сутності поняття «політичний менеджмент» зумовлює звертання до відповідних технологій як ідеологічно обгрунтованого застосування певного політичного інструментарію.

\section{Лimepamypa}

Бебик В. Політичний менеджмент суб'єктів соціально-політичного маркетингу. Політичний менеджмент. 2011. T. 6. C. 3-11. URL: http://nbuv.gov.ua/UJRN/PoMe_2011_6_3.

Беззуб'як М. Національно-державний пріоритет і громадянське суспільство. 66-те вид. Київ : Нац. пед. ун-т ім. М.П. Драгоман., Укр. АН., 2012.

Воронкова В.Г. Формування антропологічної парадигми політичного менеджменту в умовах глобалізації. Український науковий журнал «Освіта регіону: політологія психологія комунікації». URL: http://www.social-science.com.ua/jornal_content/39/communication.

Горбатенко В. Прикладна політологія: навч. посіб. Київ : Акад., 2008. 472 с.

Зиновьев А., Морозов С., Морозова Е. Политический менеджмент : учеб. пособ. Москва : ИНФРА, 2009. 236 c.

Майструк І. Управлінська культура в Японії та Сполучених Штатах Америки. Український соиіум. 2007. T. 1, № 18. С. 69-80.

Нежданов Д. Политический рынок: основы типологизации. Социум и власть. 2008. Т. 3. С. 73-82.

Перевозник Л. Політичний менеджмент: сутність та особливості розвитку в Україні в період формування громадянського суспільства. Наукові записки Кіровоградського державного педагогічного університету імені Володимира Винниченка. 2012. Серія : Icm. науки. № 15. C. 96-112. URL: http:// nbuv.gov.ua/UJRN/ Nz_i_2012_15_14.

Рудич Ф. Політологія: підручник. Київ : Либідь, 2004. 480 с.

Шульга М., Зубчик О. Політичний менеджмент. Київ : Академвидав, 2013. 160 с.

Щербак В. Політичний менеджмент: наукове поняття та політична практика. Вісник Дніпропетровського університету. 2015. Вісн. Дніпропетр. ун-ту, № 2. С. 18-24.

Blind P. Building trust in government in the twenty-first century: review of literature and emerging issues. Vienna.

Carson C.M. A historical view of Douglas McGregor's Theory Y. Management Decision. 2005. Vol. 43, no. 3. P. 450-460. URL: https:// doi.org/10.1108/00251740510589814 (accessed: 16.03.2021).

Cwalina W., Falkowski A., Newman B. I. Towards the development of a cross-cultural model of voter behavior. European Journal of Marketing. 2010. Vol. 44, no. 3/4. P. 351-368. URL: https://doi.org/ 10.1108/03090561011020462 (accessed: 16.03.2021).

Herzberg F. The motivation to work. 2nd ed. Wiley, 1959.

Maslow A.H. Motivation and personality. New York : Harper and Row, 1954. 411 p.

\section{References}

Bebyk V. Politychnyj menedzhment sub'jektiv socialjno-politychnogho marketynghu [Political management of subjects of socio-political marketing]. Politychnyj menedzhment [Political Management]. 2011. Vol. 6. pp. 3-11. URL: http://nbuv.gov.ua/UJRN/PoMe_2011_6_3.

Bezzubiak M. Natsionalno-derzhavnyi priorytet i hromadianske suspilstvo [National-state priority and civil society]. 66th ed. Kyiv: Nats. ped. un-t im. M.P. Drahomanova, Ukrainska AN. [National pedagogical university after M.P.Drahomanov], 2012.

Voronkova V.H. Formuvannia antropolohichnoi paradyhmy politychnoho menedzhmentu $\mathrm{v}$ umovakh hlobalizatsii [Formation of anthropological paradigm of political management in the conditions of globalization]. Ukrainskyi naukovyi zhurnal «Osvita rehionu: politolohiia psykholohiia komunikatsii» [Ukrainian scientific journal "Education of the region: political science, psychology of communication"].URL: http:/ / www.socialscience.com.ua/jornal_content/39/communication (accessed: 17.03.2021).

Horbatenko V. Prykladna politolohiia: navch. Posib [Applied political science]. Kyiv : Akademiia, 2008. 472 p. (in Ukrainian)

Zynovev A., Morozov S., Morozova E. Polytycheskyi menedzhment : ucheb. posob.[ Political management: textbook] Moskva : YNFRA, 2009. 236 p. (in Russian)

Maistruk I. Upravlinska kultura v Yaponii ta Spoluchenykh Shtatakh Ameryky [Management culture in Japan and the United States]. Ukrainskyi sotsium [Ukrainian society]. 2007. Vol. 1, no. 18. P. 69-80.

Nezhdanov D. Polytycheskyi rynok: osnovy typolohyzatsyy [Political market: the basis of typology]. Sotsyum y vlast. 2008. Vol. 3. P. 73-82. 
Perevoznyk L. Politychnyi menedzhment: sutnist ta osoblyvosti rozvytku v Ukraini v period formuvannia hromadianskoho suspilstva [Political management: the essence and features of development in Ukraine during the formation of civil society.]. Naukovi zapysky Kirovohradskoho derzhavnoho pedahohichnoho universytetu imeni Volodymyra Vynnychenka [Scientific notes of Kirovohrad State Pedagogical University named after Volodymyr Vynnychenko]. 2012. Seriia : Istorychni nauky, no. 15. P. 96-112. URL: http://nbuv.gov.ua/UJRN/Nz_i_2012_15_14.

Rudych F. Politolohiia: pidruchnyk [Political science:textbook]. Kyiv : Lybid, 2004. 480 p. (in Ukrainian)

Shulha M., Zubchyk O. Politychnyi menedzhment [Political management]. Kyiv : Akademvydav, 2013.160 p. (in Ukrainian)

Shcherbak V. Politychnyi menedzhment: naukove poniattia ta politychna praktyka [Political management: scientific concept and political practice]. Visnyk Dnipropetrovskoho universytetu [Bulletin of Dnipropetrovsk University]. 2015. Visnyk Dnipropetrovskoho universytetu., no. 2. P. 18-24.

Blind P. Building trust in government in the twenty-first century: review of literature and emerging issues. Vienna.

Carson C.M. A historical view of Douglas McGregor's Theory Y. Management Decision. 2005. Vol. 43 , no. 3. P. 450-460. URL: https:/ / doi.org/10.1108/00251740510589814 (accessed: 16.03.2021).

Cwalina W., Falkowski A., Newman B.I. Towards the development of a cross-cultural model of voter behavior. European Journal of Marketing. 2010. Vol. 44, no. 3/4. P. 351-368. URL: https://doi. org/10.1108/03090561011020462 (accessed: 16.03.2021).

Herzberg F. The motivation to work. 2nd ed. Wiley, 1959.

Maslow A.H. Motivation and personality. New York : Harper and Row, 1954. 411 p.

\section{Анотація}

Богаченко М. М. Сучасні наукові концепції політичного менеджменту. - Стаття.

У статті показано, що пандемія коронавірусу та спроби ії подолання в Україні чітко виявили відсутність як ефективного управління ресурсами нашої країни, що втілюється у внутрішніх і зовнішніх втратах, так і тривалого стратегування на тлі уявлення про образ майбутнього як ціль політичного розвитку. Ці обставини актуалізували необхідність розгляду наукових концепцій дослідження проблематики політичного менеджменту. Акцентовано увагу на понятті і розумінні поняття політичного менеджменту для зарубіжної політичної та вітчизняної політичної науки.

Стаття присвячена комплексному дослідженню проблематики і методології досліджень і виявленню проблем політичного менеджменту в сучасному світі. Визначено, що ключовим чинником формування політичного менеджменту в державі $є$ істинне трактування та розуміння суті двох базових категорій цього явища: менеджменту - як науки про ефективне управління саме людськими ресурсами, а також політики - як мистецтва управління різними суспільними групами, державою, народом із метою здобуття або утримання державної влади.

Розглянуто основні підходи до визначення політичного менеджменту з погляду західної науки, вітчизняної науки, їх спільне та відмінне.

Проаналізовано вже усталені часом види політичного менеджменту за основними сферами людської діяльності, серед яких соціально-політичний менеджмент або адміністративно-державне управління. Виділено форми самого політичного менеджменту: державний, державно-адміністративний, урядовий і технологічний.

У сучасному політичному процесі значення політичного менеджменту постійно зростає. Це спричинило його більшу професіоналізацію та диференціювання. Підвищення інтересу до політичного менеджменту зумовлено звуженням можливостей силового подолання проблем у сфері політичних владних відносин, утвердженням цінностей і принципів правової держави, ідеологічного і політичного плюралізму, поваги до прав меншості, свободи опозиції, толерантності. Ефективність політичного менеджменту, в тому числі і державного управління, має досягатися на основі засобів, які забезпечують виконання прийнятих рішень без репресивних інструментів.

Ключові слова: політичний менеджмент, політичний технологічний процес, політичний маркетинг, управління, стратегування.

\section{Summary}

Bogachenko M. M. Modern scientific concepts of political management. - Article.

The article shows that the coronavirus pandemic and attempts to overcome it in Ukraine have clearly revealed the lack of effective management of our country's resources, which is embodied in internal and external losses, and long-term strategy against the image of the future as a goal of political development by marriage. Therefore. These circumstances have highlighted the need to consider scientific concepts for 
the study of political management. Emphasis is placed on the concept and understanding of the concept of "political management" for foreign political and domestic political science.

The article is devoted to a comprehensive study of the problems and methodology of research and identification of problems of political management in the modern world. It is determined that the key factor in the formation of political management in the state is the true interpretation and understanding of the two basic categories of this phenomenon: management - as a science of effective management of human resources, and politics - as the art of managing various social groups, state, people to acquire or retain the state power.

The main approaches to the definition of "political management" in terms of western science, domestic science, their common and different are considered.

The already established types of political management in the main areas of human activity, including socio-political management or public administration, are analyzed. The forms of political management itself are highlighted: state, state-administrative, governmental and technological.

In the modern political process, the importance of political management is constantly growing. This led to his greater professionalization and differentiation. The increase in interest in political management is due to the narrowing of opportunities to overcome problems in the field of political power relations, the establishment of values and principles of the rule of law, ideological and political pluralism, respect for minority rights, freedom of opposition, tolerance. The effectiveness of political management, including public administration, should be achieved on the basis of means that ensure the implementation of decisions without repressive tools.

Key words: political management, political technological process, political marketing, management, strategizing. 